\title{
IF ONE THAI BOTTLE SHOULD ACCIDENTALLY FALL: HEALTH INFORMATION, ALCOHOL LABELLING AND INTERNATIONAL INVESTMENT LAW*
}

\begin{abstract}
ANDREW D MitCHELL ${ }^{\dagger}$ AND PAULA O’BRIEN ${ }^{\dagger}$
[This article considers the issues that would arise in a dispute under an international investment agreement about two innovative, public health alcohol labelling policies pursued by Thailand. One measure proposes graphic health warnings on alcoholic beverages. The other measure places extensive restrictions on the words and images that producers can use on alcoholic beverage labels. We focus on the consistency of these measures with the obligations of fair and equitable treatment and indirect expropriation. We place particular emphasis on the evidence that would likely be needed to defend these measures, including the areas where the science is somewhat tentative and might therefore pose problems for 'first-mover' States like Thailand. We conclude that there is a good chance that the warnings measure would be found compatible with investment law obligations. However, some aspects of the marketing measure are more vulnerable to findings of inconsistency.]
\end{abstract}

Keywords: international investment law - public health - non-communicable diseases - alcohol labels - warnings - marketing - industry

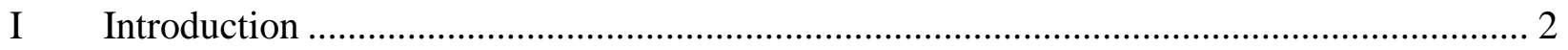

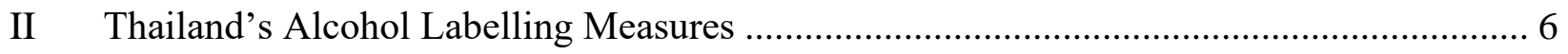

A Thailand's Alcohol Warning Label Requirements ............................................... 7

B Thailand's Alcohol Label Marketing Restrictions ............................................. 8

III Alcohol Labelling and International Investment Law .......................................... 9

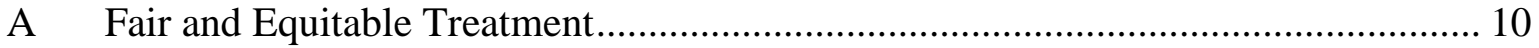

1 Arbitrariness of the Measure .............................................................. 11



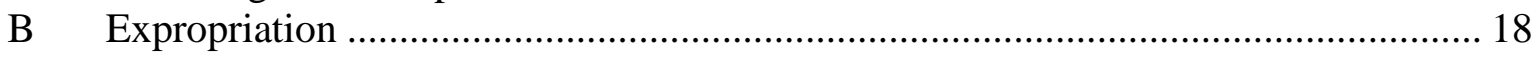



* The authors thank Tania Voon, John Holmes, Caroline Henckels, Maristela Monteiro and Rosa Sandoval for helpful comments on an earlier draft and Mark Huber, Kyle Dickson-Smith, Donia Alwan, Pei Xuan Liu and Sophia Kaiko for their research and editorial assistance, as well as Kasinee Wongsang for her translations. This research was supported in part by the Australian Research Council pursuant to the Future Fellowship scheme (project number FT130100416).

$\dagger \quad$ PhD (Cantab); LLM (Harv); Dip Int Law (Melb); LLB (Melb); BCom (Melb). Professor, Faculty of Law, Monash University; Future Fellow, Australian Research Council; Director, Global Economic Law Network.

* PhD (Melb); LLM (Cantab); BA/LLB(Hons) (Melb). Senior Lecturer, University of Melbourne Law School.; Director, Health Law and Ethics Network. 


\section{INTRODUCTION}

In 2010, Thailand introduced a proposal for health warning labels on alcoholic beverages. The labels were to include text and graphic photographs warnings about a range of risks not commonly discussed in relation to alcohol, in including suicide and family violence. Although the proposal has not been implemented, ${ }^{1}$ it still represents the high-water mark for alcohol warning labels around the world ('warning rule'). ${ }^{2}$ In 2014, Thailand continued to lead the world in regulating the packaging of alcohol with another new measure, which came into force in 2015, to restrict the words and images that could be used by producers on the label space of alcoholic beverages ('marketing rule'). ${ }^{3}$ Thailand's measures are just two among many being used in countries around the world to address the considerable burden of alcohol-related harm. This burden of death, injury, and communicable and non-communicable disease, affects developed and developing economies alike. The World Health Organization estimated that 5.3 per cent of all deaths, ${ }^{4} 7.2 \%$ of all premature mortality (69 years and under), ${ }^{5}$ and $5.1 \%$ of diseases ${ }^{6}$ worldwide in 2016 were attributable to alcohol. Alcohol ranked as the seventh leading risk factor for death and disability in the latest Global Burden of Disease study. ${ }^{7}$ Although many countries have policies to reduce harms from alcohol, the World Health Organization has reported that, '[a]lcohol policy development and implementation has improved globally but are still far from accomplishing effective protection of populations ... The skewed prevalence of effective alcohol policies in higher-income countries raises issues of global health equity... .8

Alan Adcock, Aaron Le Marquer and Lennard Meulens 'Thailand's Increasingly Stringent Regulatory Controls on the Packaging and Labeling of Alcoholic Beverages' (Tilleke \& Gibbons, 28 August 2015) <www.tilleke.com/resources/thailands-increasingly-stringent-regulatory-controls-packaging-and-labeling-alcoholicbeve> accessed 4 February 2019. WTO, 'Notification' WTO Doc G/TBT/N/THA/332 (21 January 2010); WTO ‘Notification - Addendum’ WTO Doc G/TBT/N/THA/332/Add.1 (30 March 2010) (Addendum).

3 WTO, 'Notification', WTO Doc G/TBT/N/THA/437 (28 March 2014); WTO, 'Notification', WTO Doc G/SPS/N/THA/221 (20 January 2014); WTO, 'Notification - Addendum' WTO Doc G/SPS/N/THA/221/Add.1. (10 April 2015).

$4 \quad$ WHO, 'Global Status Report on Alcohol and Health 2018' (2018) 63.

$5 \quad$ Ibid 78.

6 Ibid 85.

7 GBD 2017 Risk Factor Collaborators, 'Global, Regional, and National Comparative Risk Assessment of 84 Behavioural, Environmental and Occupational, and Metabolic Risks or Cluster Risks for 195 Countries and Territories, 1990-2017: A Systematic Analysis for the Global Burden of Disease Study 2017' (2018) 392 The Lancet 1923, 1964.

8 WHO 'Global Status Report' (n 4) xvi. 
The Thai warning rule, although not implemented, was a public health game-changer. In 2018, there were only 56 countries that required labels with advice, warnings or information about the risks from the consumption of alcohol. ${ }^{9}$ This health information is generally presented as text only, with few images and with messages which concentrate on warning about under-age drinking, drinking during pregnancy and drinking and driving. ${ }^{10}$ The archetypal example is found in the United States. ${ }^{11}$ By contrast, the proposed Thai warning scheme was confronting and controversial, because it took a major step forward and adopted the highly effective tobacco-style warnings, ${ }^{12}$ including realistic photo-style images, covering a large area of the container, and warning about risks that many people do not (or do not want to) associate with a product like alcohol, including domestic violence, impotence and suicide. The Thai government was the first government to propose such warnings for alcohol and, in doing so, signalled to the alcohol industry a major shift in public health policy. Since the Thai scheme was announced in 2010, we have seen some, but not all, of the Thai labelling features in other new labelling schemes, including those in Kenya, ${ }^{13}$ Ireland, ${ }^{14}$ South Korea, ${ }^{15}$ South Africa, ${ }^{16}$ and most recently, the Yukon Territory in Canada. ${ }^{17}$

World Health Organization, Global Status Report on Alcohol and Health 2018 (2018) 111-12.

'Health Warning Labeling Requirements' (International Alliance for Responsible Drinking, April 2016) <http://www.iard.org/policy-tables/health-warning-labeling-requirements/> accessed 4 February 2019.

Since 1989, the US has required the same text only warning that states: 'GOVERNMENT WARNING: (1) According to the Surgeon-General, women should not drink alcoholic beverages during pregnancy because of the risk of birth defects. (2) Consumption of alcoholic beverages impairs your ability to drive a car or operate machinery, and may cause health problems.' The regulation sets only the most basic legibility requirements: the warning must be on the container, it must be legible in ordinary conditions and the font must comply with a prescribed size depending on the size of the container: Alcohol, Tobacco Products and Firearms, 27 CFR 1998 (US) \$16.21-16.22 (1998, USA).

See 'Tobacco Free Initiative' (WHO, 2019) <http://www.who.int/tobacco/healthwarningsdatabase/en/> accessed 5 February 2019; David Hammond, 'Health Warning Messages on Tobacco Products: A Review' (2011) 20 Tobacco Control 327.

WTO, 'Notification', WTO Doc G/TBT/N/KEN/282 (1 March 2011).

WTO, 'Notification', WTO Doc G/TBT/N/IRL/2 (7 June 2016). See Public Health (Alcohol) Bill 2015 [Law No 120 of 2015] (Ireland).

WTO, 'Notification', WTO Doc G/TBT/N/KOR/664 (29 July 2016).

WTO, 'Notification', WTO Doc G/TBT/N/ZAF/48/Rev.1 (3 December 2014). For further detail of the proposal, see Global Agricultural Information Network, 'Regulation Amendment on Container Labels of Alcoholic Beverages' (30 January 2015); Regulations Relating to Health Messages on Container Labels of Alcoholic Beverages (24 August 2007, South Africa) reg 764, Annexure A.

Ian Austen 'Yukon Government Gives In to Liquor Industry on Warning Label Experiment' The New York Times (London, 6 January 2018) <www.nytimes.com/2018/01/06/world/canada/yukon-liquor-alcohol-warnings.html> accessed 4 February 2019. The Yukon Territory is one of Canada's three federal territories. 
There are also some indications that Thailand might again be considering introducing graphic warnings for alcohol. ${ }^{18}$

Thailand has also gone further with its marketing rule than any other country. Although many countries prohibit false, misleading or deceptive product representations, either through the general law ${ }^{19}$ or through a food-specific law, ${ }^{20}$ and there might be industry self-regulatory standards for label content in some countries, ${ }^{21}$ the Thai marketing rule specifically prohibits a range of common alcohol marketing techniques. These include: the linking of alcohol to sports, recreation or charities; the use of cartoon-like images; the use of celebrities; and some descriptions of the beverage's benefits and qualities. ${ }^{22}$ These label restrictions complement other prohibitions on alcohol marketing in Thailand, which prevent advertising encouraging alcohol consumption or displaying a picture of an alcoholic beverage or a person consuming an alcoholic beverage. ${ }^{23}$ The marking rule reflects an understanding that the alcohol industry not only uses traditional media to sell its products. It also sees the 'packaging' of the beverage as a powerful marketing medium.

See WTO, 'Minutes of the Meeting of 14-15 June 2017', WTO Doc G/TBT/M/72 (25 September 2017) paras 3.122 (US), 3.124 (EU), 3.129 (NZ); WTO, 'Minutes of the Meeting of 29-30 March 2017', WTO Doc G/TBT/M/71 (2 June 2017) paras 2.139 (EU), 2.140 (Canada); WTO, 'Minutes of the Meeting of 10-11 November 2016', WTO Doc G/TBT/M/70 (17 February 2017) paras 2.151 (EU), 2.153 (NZ). Thailand has previously committed to notifying the TBT Committee on the progress of a regulation on warnings: WTO, 'Minutes of the Meeting of 20-21 June 2018', WTO Doc G/TBT/M/75 (14 September 2018) para 4.91 (Thailand); WTO, 'Minutes of the Meeting of 21-22 March 2018', WTO Doc G/TBT/M/74 (22 May 2018) para 2.113 (Thailand); WTO, 'Minutes of the Meeting of 8-9 November 2017', WTO Doc G/TBT/M/73 (6 March 2018) para 2.84 (Thailand); WTO, 'Minutes of the Meeting of 10-11 November 2016', WTO Doc G/TBT/M/70 (17 February 2017) para 2.156 (Thailand). TBT Committee members continue to ask for updates on this information: WTO, 'Minutes of the Meeting of 20-21 June 2018', WTO Doc G/TBT/M/75 (14 September 2018) paras 4.84-4.90; WTO, 'Minutes of the Meeting of 21-22 March 2018', WTO Doc G/TBT/M/74 (22 May 2018) paras 2.108-2.112; WTO, 'Minutes of the Meeting of 8-9 November 2017', WTO Doc G/TBT/M/73 (6 March 2018) paras 2.77-2.83.

19 See eg in Australia, Competition and Consumer Act 2010 (Cth) sch 2, s 18 ('Deceptive conduct'), s 29 ('False or misleading representations about goods or services') s 33 ('Misleading conduct as to the nature etc. of goods').

20 See eg Regulation (EU) No 1169/2011 of the European Parliament and of the Council of 25 October 2011, art 7(1).

21 See eg in the United Kingdom, Code of Practice on the Naming, Packaging and Promotion of Alcoholic Drinks (5th edn, Portman Group December 2015) cl 3.

22 WTO, 'Notification', WTO Doc G/TBT/N/THA/437 (n 3); WTO, 'Notification', WTO Doc G/SPS/N/THA/221 (n 3); WTO, 'Notification - Addendum' WTO Doc G/SPS/N/THA/221/Add.1 (n 3).

23 Ratchakorn Kaewpramkusol et al, 'Brand Advertising and Brand Sharing of Alcoholic and Non-alcoholic Products and the Effects on Young Thai People's' Alcohol Use: A Qualitative Focus Group Study' (2019) 38 Drug Alcohol Review 284, 285; Ratchakorn Kaewpramkusol et al, 'A Qualitative Exploration of the Thai Alcohol Policy in Regulating Alcohol Industry's Marketing Strategies and Commercial Activities' (2019) 38 Drug Alcohol Review 25, 26. Although the Thai alcohol advertising rules might appear quite restrictive on their face, it has been argued that the industry regularly uses novel marketing means to circumvent the restrictions: see Ratchakorn Kaewpramkusol et al, 'A Qualitative Exploration of the Thai Alcohol Policy in Regulating Alcohol Industry's Marketing Strategies and Commercial Activities' (2019) 38 Drug Alcohol Review 25. 
Although considerable attention has been given to regulating the packaging of tobacco as a means to reduce population use of the product (such as has been done through tobacco plain packaging), ${ }^{24}$ there has been much less attention paid in public health research and policy circles to the power of the alcohol label. The label is 'valuable real estate', ${ }^{25}$ despite being a relatively tiny physical space in the case of both tobacco and alcohol. With alcohol, increasing attention is being given to adding government warnings and health information onto packaging, but this Thai measure also encourages States to think about removing industry information from the label.

This article examines the legal issues that the Thai warning and marketing rules raise in international investment law. In the context of international trade law, these innovative public health measures have been the subject of extensive discussion and debate in the World Trade Organization's Committee on Technical Barriers to Trade (WTO TBT Committee) since 2010. The proposals have been exceptionally contentious with the major alcohol producing WTO members, including the European Union, the United States, Australia, Chile, Mexico and New Zealand. These members have raised numerous trade-related concerns with Thailand about its proposals, with a particular concern being an alleged lack of scientific evidence supporting the measures. ${ }^{26}$ Furthermore, the Thai warning rule bears almost all the label features that our previous research has identified as objectionable to alcohol-exporting WTO members and their domestic alcohol industries. ${ }^{27}$ It seems quite possible that either or both measures could be subject to formal WTO dispute settlement in the future. ${ }^{28}$

It also seems possible that either or both Thai measures could also be subject to international investment arbitration challenge. The recent experience with packaging of tobacco, including

For the legal issues, see: Tania Voon, Andrew D Mitchell, Jonathan Liberman (eds), Public Health and Plain Packaging of Cigarettes (Edward Elgar 2012). For a review of the evidence for plain packaging, see Crawford Moodie et al, 'Plain Tobacco Packaging: A Systematic Review' (Centre for Tobacco Control Research 2012).

Australian Alcoholic Beverage Industries, 'Submission to the Labelling Review Response Secretariat on Alcoholic Beverages' (5 September 2011) 14.

See eg WTO, 'Minutes of the Meeting Held of 24-25 March 2010', WTO Doc G/TBT/M/50 (28 May 2010$)$ paras 4 (Mexico), 5 (EU), 11 (US); WTO, 'Minutes of the Meeting of 23-24 June 2010', WTO Doc G/TBT/M/51 (1 October 2010) para 237 (EU); WTO, 'Minutes of the Meeting Held of 24-25 March 2010', WTO Doc G/TBT/M/50 (28 May 2010) paras 6 (Argentina), 7 (NZ), 11 (US).

Paula O'Brien and Andrew D Mitchell, 'On the Bottle: Health Information, Alcohol Labelling and the WTO Technical Barriers to Trade Agreement' (2018) 12 Queensland University of Technology L Rev 124.

We have examined some of the international trade law issues relating to alcohol labelling measures, including the Thai measures, elsewhere: see ibid 43-54; Paula O'Brien et al, 'Marginalising Health Information: Implications of the Trans-Pacific Partnership for Alcohol Labelling' (2017) 41 MelbULRev 341, 367-75. 
Uruguay's use of graphic warnings ${ }^{29}$ and Australia's plain packaging, ${ }^{30}$ reinforces this possibility. To date, there has been no analysis of the consistency of the Thai measures with international investment law. Given the potential for these measures to influence alcohol control in other countries, it is important to explore the range of legal issues that would arise and require resolution in a challenge under international investment law. Understanding these issues is also intended to assist governments in preparing public health alcohol labelling measures, such as those being pursued by Thailand, in a manner that is most likely to be considered consistent with international investment law.

In Part II, we outline the details of Thailand's two alcohol labelling measures. In Part III, we consider the issues and likely arguments that could arise in a dispute under an international investment agreement about these measures. We focus on the obligations of fair and equitable treatment and indirect expropriation. We place particular emphasis on the evidence that would likely be needed and used to defend these measures, including the areas where the science is somewhat tentative and might therefore pose problems for innovative, 'first-mover' States like Thailand. Our conclusion in Part IV repeats our view that there is a good chance that the Thai warning rule would be found to be compatible with investment law obligations. However, there are aspects of the marketing rule that are more vulnerable to challenge and findings of inconsistency.

\section{Thailand’s Alcohol Labelling Measures}

In this Part, we outline Thailand's two alcohol labelling measures: the warning rule and the marketing rule. We provide considerable detail about each measure, as we use that detail in our analysis of the likely consistency of the Thai proposals with international investment law in Part III.

See Philip Morris Brands Sàrl, Philip Morris Products SA and Abal Hermanos SA v Oriental Republic of Uruguay, ICSID Case No ARB/10/7, Award (8 July 2016) ('Phillip Morris v Uruguay').

30 See Philip Morris Asia Ltd v Commonwealth of Australia, PCA Case No 2012-12, UNCITRAL, Award on Jurisdiction and Admissibility (17 December 2015) ('Phillip Morris v Australia'). 


\section{A Thailand's Alcohol Warning Label Requirements}

In January 2010, Thailand notified the WTO of a proposed alcohol control measure that would have required warnings on alcoholic beverage labels. ${ }^{31}$ As discussed above, this measure has not passed into law yet. The warning label rule consisted of three parts. The first prohibited any words on alcoholic beverage packaging that would mislead the consumer into believing that: (i) alcohol can improve health; and (ii) one alcoholic beverage is less 'toxic' than another. The second part required that all alcoholic beverages bear the words, 'sale of alcoholic beverages to persons under 20 years old is prohibited'.

The third, and most significant part of the rule, for the purposes of this article, was a set of warnings. These warnings consisted of text and colourful photograph-style images. The contents of the warnings, as found in the English translations provided by Thailand, were as follows: (i) drinking alcohol causes hypertension and liver cirrhosis; (ii) alcohol intoxication leads to accidents; (iii) drinking alcohol leads to unconsciousness and even death; (iv) drinking alcohol leads to inferior sexual performance; (v) drinking alcohol leads to adverse health effects and family problems; and (vi) drinking alcohol is a bad influence on children and young people. ${ }^{32}$ A later translation offered by the Thai government claimed that the statements actually used the word 'could', such as 'drinking alcohol could be a bad influence on children and young people', thereby softening the alleged causal connection between consumption and harm. ${ }^{33}$ All alcoholic beverage packaging was to carry one of the warnings, which were to be displayed in a prescribed four colours and six fonts, and be affixed in a permanent manner. The labels were to constitute a large part of the packaging, being $50 \%$ of the largest side of a square container and $30 \%$ of the surface G/TBT/NHA 332/Add.1 (n 2).

“(i): ดื่มสุรา ทำให้เป็นโรคตับแข็ง; (ii) ดื่มสุราแล้วขับขี่ ทำให้พิการและตายได้; (iii) ดื่มสุรา ทำให้ขาดสติและเสียชีวิตได้; (iv) ดื่มสุรา ทำให้เสื่อมสมรรถภาพทางเพศ; (v) ดื่มสุรา ทำร้ายตัวเอง ทำลายลูกและครอบครัว; (vi) ดื่มสุรา เป็นแบบอย่างที่ไม่ดีต่อเด็กและเยาวชน": see WTO, 'Notification' WTO Doc G/TBT/N/THA/332 (n 2); For unofficial English translations, see: Global Agricultural Information Network, 'Draft Regulation on Alcohol Graphic Warning Labeling’ (Report No TH0015, 28 January 2010).

33 Areekul Puangsuwan and Thaksaphon Thamarangsi, 'Why Thailand Should Have The Pictorial Warning Label on Alcoholic Beverage Packages?' (Thailand Centre for Alcohol Studies and International Health Policy Program June 2010) 6 . 
area of the entire package for other shapes. The six labels were to be rotated every 1000 units of production. ${ }^{34}$

\section{B Thailand's Alcohol Label Marketing Restrictions}

In April 2014, Thailand notified the WTO TBT Committee and the WTO's Committee on Sanitary and Phyto-Sanitary Measures of a new alcohol control measure to restrict the content that would be permitted on alcoholic beverage labels. ${ }^{35}$ The marketing rule came into effect on 22 April 2015, although non-compliant products exported before 22 March 2015 were able to be sold until 18 October $2015 .^{36}$

The marketing rule prohibits the use of certain words and images on alcoholic beverage labels. The English translation of the Thai rule is not completely clear but, in essence, the rule seems to have two parts. The first part of the measure prohibits messages which are 'unfair to consumers' or lead to 'bad effects to the society as a whole'. Messages which fall within these prohibitions include those which:

- $\quad$ are 'false or exaggerated';

- 'mislead' about the 'contents of products or services' by 'using or referring to academic reports, statistic data or something that is not true or exaggerated'; ${ }^{\prime 3}$

- directly or indirectly support illegality or immorality or 'discredit ...the national culture'; and

- lead to 'disharmony' or 'prejudice' to the society or the people.

The second part of the measure prohibits messages which 'directly or indirectly persuade[] [people] to consume' alcohol or which 'pretentiously exaggerate[] the benefit or quality of

WTO, 'Notification’ WTO Doc G/TBT/N/THA/332 (n 2) paras 3-4.

WTO, 'Notification', WTO Doc G/TBT/N/THA/437 (n 3); WTO, 'Notification', WTO Doc G/SPS/N/THA/221 (n 3); WTO, 'Notification - Addendum' WTO Doc G/SPS/N/THA/221/Add.1 (n 3).

WTO, 'Thailand - Draft Notification on Alcoholic Beverages Control, Rules, Procedure and Condition for Labels of Alcoholic Beverages’ WTO doc G/TBT/W/422 (18 June 2015).

'Brief of Technical Documents' (copy supplied by Thai TBT Enquiry Point on 26 April 2018) (on file with authors) ('Enquiry Point Technical Document'). The Enquiry Point Technical Document is specifically marked with the words, 'This Technical Documents (sic) is only to explain a Regulation's intention, has no legal status and legal effect'. 
alcoholic beverages'. Messages which will be inconsistent with these prohibitions include those which:

- 'introduce[] an attitude that drinking can lead to social and sexual success including health'; 38

- are about or include pictures of athletes, artists, singers, movie stars, actors;

- use cartoons ('except the picture of alcoholic beverage trade mark which was registered as a trade mark certificate before the enforcement of this notification'); ${ }^{39}$

- use the promise of a donation to charity from the purchase or consumption of alcohol; and

- encourage participation in activities such as music, sports, contests or recreation.

The rule applies to all alcoholic beverages in Thailand, local or imported, except for alcoholic beverages which are to be exported from Thailand or which are manufactured or imported for 'the purposes of testing, analysis or research ... for non-commercial benefits. ${ }^{40}$

\section{ALCOHOL LABELLING AND INTERNATIONAL INVESTMENT LAW}

Foreign investors affected by Thailand's alcohol labelling requirements (such as those with investments in manufacturing, distribution, or sale of alcohol products) might use international investment law to challenge new regulations they perceive as harmful to their interests. To do so, these investors would likely rely upon obligations in international investment agreements (IIAs) between their home State(s) and Thailand concerning the treatment of investors and investments from that State. Thailand is currently a party to at least 68 such IIAs. ${ }^{41}$

Ibid.

The qualification which exempts registered trademarks from the operation of the rule is in the Enquiry Point Technical Document and not in the regulation itself: see ibid.

WTO, 'Notification', WTO Doc G/TBT/N/THA/437 (n 3).

These include those entered into by Thailand as a Member of the Association of Southeast Asian Nations. According to the United Nations Conference on Trade and Development, 59 of Thailand's IIAs are in force. These include agreements with: Argentina, Australia, Bahrain, Bangladesh, the Belgium-Luxembourg Economic Union, Bulgaria, Cambodia, Canada, China, Croatia, the Czech Republic, Egypt, Finland, Germany, Hong Kong (China SAR), Hungary, India, Indonesia, Israel, Japan, Jordan, the Democratic People's Republic of Korea, the Republic of Korea, 
Three aspects of Thailand's warnings rule could potentially be challenged under international investment law, individually or cumulatively: mandating particular graphic images in specific colours on the label; requiring a warning of a size that encroaches on the promotional parts of the label or product design; and conveying particular meanings in the graphic label (e.g. targeting alcohol use per se rather than excessive alcohol use, or linking alcohol to less direct effects such as family violence). Meanwhile, there may also be arguments that Thailand's marketing rule's strict prohibition on the use of certain images and terms violates principles in international investment law.

Claims against these aspects of measures are most likely to be based on two core investment obligations that are included in most IIAs: fair and equitable treatment (FET) and indirect expropriation. We consider these obligations, in turn, in relation to the Thai warning rule and marketing rule. The analysis provides insight into the ways in which an investment treaty tribunal might assess the labelling requirements in a claim by a foreign investor against a host State. We conclude that Thailand's proposed warning rule requirements are generally consistent with the traditional international investment obligations of FET and indirect expropriation. However, there are aspects of Thailand's marketing rule which are more contentious because of its seemingly broad scope and its apparent restriction of producers' freedom to include descriptions of the basic properties of their alcohol products.

\section{A Fair and Equitable Treatment}

The FET clause in most IIAs (particularly older treaties) is typically broad and unqualified, such as: $^{42}$

the Lao People's Democratic Republic, Myanmar, the Netherlands, New Zealand, Peru, the Philippines, Poland, Romania, Slovenia, Sri Lanka, Sweden, Switzerland, Taiwan (Province of China), Turkey, the United Kingdom, the United States of America, and Viet Nam. See: UNCTAD, 'International Investment Agreements Navigator: Thailand' (Investment Policy Hub 2013) <http://investmentpolicyhub.unctad.org/IIA/CountryBits/207> accessed 5 February 2019.

42 See eg, Agreement between the Swiss Confederation and the Kingdom of Thailand on the Promotion and Reciprocal Protection of Investments, (Signed 17 November 1997, entered into force 21 July 1999) Art 4.1; Agreement between the Government of the Kingdom of Thailand and the Government of the Republic of India for the Promotion and Protection of Investments (Signed 10 July 2000, entered into force 13 July 2001) Art 3(2). 
Investments and returns of investors of each Contracting Party shall at all times be accorded fair and equitable treatment.

The meaning of FET is unsettled and dependent on the precise wording of the clause in the applicable IIA (among other clauses present, notably the most-favoured nation clause), the circumstances of the dispute, ${ }^{43}$ and the approach of the particular ad hoc tribunal. Notwithstanding this variability, tribunals routinely look to earlier awards for guidance, in what may be considered de facto jurisprudence constante. ${ }^{44}$ One such award to which many subsequent tribunals have turned is Waste Management II, where the tribunal stated that a breach of the FET standard arises from conduct that is:

grossly unfair, unjust or idiosyncratic, is discriminatory and exposes the claimant to sectional or racial prejudice, or involves a lack of due process leading to an outcome which offends judicial propriety - as might be the case with a manifest failure of natural justice in judicial proceedings or a complete lack of transparency and candour in an administrative process. In applying this standard, it is relevant that the treatment is in breach of representations made by the host State which were reasonably relied on by the claimant. ${ }^{45}$

The most relevant aspects of the FET obligation for alcohol labelling measures are the arbitrariness of the measure and the legitimate expectations of the foreign investor, as we explain in turn below.

\section{Arbitrariness of the Measure}

In 2016, the tribunal in Philip Morris v Uruguay applied the prevailing legal standard pertaining to 'arbitrariness' (derived from International Court of Justice ${ }^{46}$ ) to Uruguayan tobacco labelling

Christoph Schreuer, 'Fair and Equitable Treatment in Arbitral Practice' (2005) 6 JWIT 3, paras 319-320.

Florian Grisel, 'The Sources of Foreign Investment Law' in Joost Pauwelyn, Jorge Vinuales and Zachary Douglas (eds), The Foundations of International Investment Law (OUP 2014) vol II, 212.

See Waste Management Inc v United Mexican States, ICSID Case No ARB(AF)/00/3, Award (30 April 2004) para 98. As at 1 June 2018, this paragraph has been cited by at least 66 tribunals: see 'Jurisprudence Citator' (InvestorState Law Guide 2019) <www.investorstatelawguide.com> accessed 4 February 2019.

Elettronica Sicula SpA (ELSI) (United States of America v Italy) [1989] ICJ Rep 15, 15. 
measures. ${ }^{47}$ The majority of the tribunal determined that a measure would not be arbitrary if that measure was: ${ }^{48}$

- not entirely lacking in justification;

- not 'wholly disproportionate';

- an attempt to address a 'legitimate underlying aim'; and

- adopted in good faith.

The Rumeli Telecom v Kazakhstan tribunal provided further guidance as to the meaning of reasonableness in the context of public policy measures, stating "[t]he standard of "reasonableness" has no different meaning than the "fair and equitable treatment" standard with which it is associated. Therefore, it requires that the State's conduct bears a reasonable relationship to some rational policy. ${ }^{49}$

Thailand's proposed warning rule that alcoholic beverages include one of six labels (comprised of both graphic and text warnings) covering a significant (30-50\%) portion of the alcohol product, is broadly analogous to Uruguay's mandating of one of five graphic labels on packages of tobacco products, comprising $80 \%$ of the front and back of the package. ${ }^{50}$ The Philip Morris v Uruguay

Phillip Morris v Uruguay (n 29) para 390. The Uruguayan Presidential Decree 287 implements 80/80 Regulation, which imposes an increase in the size of prescribed health warnings of the surface of the front and back of the cigarette packages from $50 \%$ to $80 \%$, leaving only $20 \%$ of the cigarette pack for trademarks, logos and other information.

The majority of the tribunal stated with respect to the $80 / 80$ requirement: 'In the end, the question is whether the $80 \%$ limit in fact set was entirely lacking in justification or wholly disproportionate, due account being taken of the legitimate underlying aim - viz., to make utterly clear to consumers the serious risks of smoking.' Phillip Morris $v$ Uruguay (n 29) para 419. Further, 'In short, the 80/80 Regulation was a reasonable measure adopted in good faith to implement an obligation assumed by the State under the [Framework Convention on Tobacco Control]. It was not an arbitrary, grossly unfair, unjust, discriminatory or a disproportionate measure, in particular given its relatively minor impact on Abal's business.': ibid para 420. The dissenting arbitrator stated 'Article 3(2)'s guarantee of "fair and equitable treatment," and the related requirements of reasonableness and proportionality, require an objective consideration of the extent to which a governmental measure is rationally related to, or fairly advances, the State's articulated objectives. That consideration must give considerable deference to a State's choice among competing means to accomplish its objectives, its assessment of the likelihood that particular means will be effective, and its weighing of costs and benefits.': ibid Dissent, para 144.

Rumeli Telekom AS and Telsim Mobil Telekomikasyon Hizmetleri AS v Kazakhstan, ICISD Case No ARB/05/16, Award (29 July 2008) para 671 (as cited in Phillip Morris v Uruguay (n 29) para 135).

Ordinance 514 required the use of pictograms consisting of five images combined with five statements to be printed on $50 \%$ of the display areas (lower half) of all packs of cigarettes and tobacco products. Phillip Morris v Uruguay (n 29) para 109. The size of the warnings was increased by Presidential Decree 287: Phillip Morris v Uruguay (n 29) para 121. 
tribunal unanimously determined that the requirement of graphic warnings comprising $80 \%$ of the surface area did not breach the FET standard. ${ }^{51}$ The claim focused on the size of the warning rather than the standardisation of labels through the restriction to five types of labels ${ }^{52}$ or the content of the labels. ${ }^{53}$ Nevertheless, the tribunal's award provides guidance as to a possible analytical approach under investment law to any product labelling requirement carried out for a public policy purpose.

In accordance with the tribunal's approach, there are unlikely to be findings against either the use of graphic labels on alcoholic beverages or the specific content of the Thai warning messages. These are both features of the labels that may potentially be contested, as Thailand is the first country to introduce graphic, photo-style labels, and to warn about harms from alcohol including family violence and suicide. To start, Thailand would almost certainly be found to have a legitimate aim underpinning its preferred health information labelling policy. It has explained repeatedly in the WTO TBT Committee that its population suffers a higher burden of harm from the consumption of alcohol than the global average. ${ }^{54}$ It has also specifically argued that the graphic labels are needed because 'marketing, including advertising through beverage packaging, [have] been the most important vector for the alcohol epidemic in Thailand. ${ }^{55}$

Both the graphic nature of the warnings and their content are also likely to be seen as justified and not 'wholly disproportionate' means of fulfilling the highly legitimate aim of addressing harms from alcohol. There is no indication of bad faith on the part of Thailand. In relation to the graphic nature of the warnings, there are admittedly few alcohol-specific studies which would support the use of this particular style of imagery. ${ }^{56}$ However, there are multiple good studies of the use of pictogram-style alcohol warnings, which may be relied upon to suggest the reasonableness of

\section{Ibid 420.}

Ibid paras 9-12, 241, 404.

Ibid para 419.

Puangsuwan and Thamarangsi (n 33) 5. See also Surasack Chaiyasong, 'Drinking Patterns Vary by Gender, Age and Country-level Income: Cross-country Analysis of the International Alcohol Control Study' (2018) 37(S2) Drug Alcohol Review S53, S57-58; Orratai Waleewong et al, 'Harm from Others' Drinking-related Aggression, Violence and Misconduct in Five Asian Countries and the Implications' (2018 56 Int J Drug Policy 101, 104-5.

WTO, 'Minutes of the Meeting of 3-4 November 2010', WTO Doc G/TBT/M/52, (10 March 2011) para 246 (Thailand).

See Lisa M Thomson, Brian Vandenburg and John Fitzgerald, ‘An Exploratory Study of Drinkers'of Drinkers’ Views of Health Information and Warning Labels on Alcohol Containers' (2012) 31(2) Drug and Alcohol Rev 240. 
accompanying text-based warnings with pictures. ${ }^{57}$ These studies suggest the effectiveness of graphic warning labels on alcoholic beverage labels to create knowledge and understanding about the risks of consumption, and to shape attitudes and intentions about drinking behaviour, all of which are important precursors to changing consumption and, in turn, reducing harm in individuals and at the population level. ${ }^{58}$ Thailand would also likely find assistance in the literature about the effectiveness of graphic warnings on tobacco, ${ }^{59}$ which it has referred to in the course of discussions in the WTO TBT Committee. ${ }^{60}$ In relation to the content of the warnings, the extensive body of research about the association between alcohol consumption and the range of harms represented in the Thai labels ${ }^{61}$ would also protect against a finding of a breach of the FET standard. The warnings about drink driving would undoubtedly be uncontroversial. ${ }^{62}$ There might be more contestation about linking alcohol with family violence or suicide, for example, or the suggestion that it is drinking per se (rather than excessive drinking of alcohol), ${ }^{63}$ but it is doubtful that these aspects of the warnings would be considered to be 'wholly disproportionate'.

The more controversial rule is likely to be Thailand's marketing rule. However, it is also unlikely that this rule would be considered arbitrary in its entirety. It would be difficult to prove in a dispute that Thailand does not have a legitimate reason or aim when imposing such measures and that such measures are in bad faith. As explained by Thailand, alcoholic beverage labels are a marketing

See Kate Vallance et al, "We Have a Right to Know": Exploring Consumer Opinions on Content, Design and Acceptability of Enhanced Alcohol Labels' (2018) 53 Alcohol and Alcoholism 20; Eric Hobin et al, 'Testing the Efficacy of Alcohol Labels with Standard Drink Information and National Drinking Guidelines and Consumers' Ability to Estimate Alcohol Consumption' (2018) 53 Alcohol and Alcoholism 3.

Ibid.

Hammond (n 12), 334; Puangsuwan and Thamarangsi (n 33) 9-10.

WTO, 'Minutes of the Meeting of 23-24 June 2010' (1 October 2010) WTO Doc G/TBT/M/51 para 249; WTO, 'Minutes of the Meeting of 3-4 November 2010', WTO Doc G/TBT/M/52, (n 55) para 247.

Puangsuwan and Thamarangsi (n 33) $13-23$.

Alcohol producers themselves are committing to including messages about drink driving on their products: see Beer Wine Spirits, 'Providing Consumer Information and Responsible Product Innovation' (2016) $<$ http://www.producerscommitments.org/commitments/providing-consumer-information-and-responsible-productinnovation/> accessed 5 February 2019.

In response to Thailand's notification of labelling measures, some WTO members (such as the EU, Mexico and Chile) have argued that it is not drinking per se, but excessive drinking that is a general cause of concern, and that moderate drinking is consistent with a healthy lifestyle. WTO, 'Minutes of the Meeting of 24-25 March 2010' (28 May 2010), WTO Doc G/TBT/M/50, paras 3-12; WTO, 'Minutes of the Meeting of 23-24 June 2010' (1 October 2010) WTO Doc G/TBT/M/51, paras 237-251; WTO, 'Minutes of the Meeting of 3-4 November 2010', WTO Doc G/TBT/M/52, (n 55) paras 234-248. See also Annie Britton and Michael Marmot, 'Different measures of alcohol consumption and risk of coronary heart disease and all-cause mortality: 11-year follow-up of the Whitehall II Cohort Study' (2004) 99 Addiction 109 (demonstrating that non-drinkers and those drinking more than $248 \mathrm{~g} /$ week had approximately a twofold increased risk of mortality, in comparison to moderate drinkers, consuming $10-80 \mathrm{~g}$ of alcohol each week). 
tool that influence consumer decision-making at the point of sale, particularly among young people. ${ }^{64}$ In addition, the marketing rule's introduction was foreshadowed a year before it was implemented, ${ }^{65}$ and stakeholders were provided with additional time to bring non-compliant labels into conformity. ${ }^{66}$ Finally, the measure itself grandfathers pre-existing registered trademarks that might otherwise be noncompliant. ${ }^{67}$ But an argument about a breach of the FET standard may be made on the basis that the rule lacks specificity and clarity and is potentially so broad as to be unreasonably burdensome on investors. This concern has been particularly pronounced in respect of the marketing rule's ban on 'cartoons' and the use of exaggeration in the description of the product's qualities and benefits. The US has complained repeatedly in the WTO TBT Committee about the rule's 'vague language and the excessive enforcement discretion it conferred on individual officers'. ${ }^{68}$ New Zealand has described this particular rule as 'unworkable'. ${ }^{69}$ Thailand has been reluctant so far to clarify the exact scope of these rules, despite repeated requests in the WTO TBT Committee to do so. ${ }^{70}$ In an investment dispute, Thailand may be challenged about the evidence to support how the restriction of cartoons and certain words will serve the aim of eliminating positive attitudes towards alcohol products. It is not clear to us that there is evidence available to support such expansive restrictions. Thailand would be on firmer ground if it clarified and restricted the scope of the rule, for example, to allow descriptions of the properties associated with certain styles of wine and to only ban images which would appeal to children or mature minors (such as those used in children's cartoons or teenagers' computer games).

WTO, 'Minutes of the Meeting of 20-21 June 2018', WTO Doc G/TBT/M/75 (n 18) para 4.92 (Thailand); WTO, 'Minutes of the Meeting of 8-9 November 2017', WTO Doc G/TBT/M/73(n 18) para 2.84 (Thailand).

See C Henckels, 'A Duty to Consult Foreign Investors When Changing the Regulatory Framework? Implications for Tobacco Control and Beyond' (In this Special Issue).

For information on when the marketing rule was foreshadowed: WTO, 'Notification', WTO doc G/TBT/N/THA/437 (n 3). For information on when sstakeholders were required to comply: WTO, 'Minutes of the Meeting of 10-11 November 2016', WTO Doc G/TBT/M/70 (n 18) para 2.152 (Australia).

Enquiry Point Technical Document (n 37) 2, part (2)(d).

WTO, 'Minutes of the Meeting of 29-30 March 2017', WTO Doc G/TBT/M/71 (n 18) para 2.137 (US).

WTO, 'Minutes of the Meeting of 10-11 November 2016', WTO Doc G/TBT/M/70 (n 18) para 2.153 (NZ).

WTO, 'Minutes of the Meeting of 20-21 June 2018', WTO Doc G/TBT/M/75 (n 18) paras 4.86-4.87; WTO, 'Minutes of the Meeting of 21-22 March 2018', WTO Doc G/TBT/M/74 (n 18) paras 2.107 (US), 2.113 (Thailand); WTO, 'Minutes of the Meeting of 8-9 November 2017', WTO Doc G/TBT/M/73 (n 18) paras 2.76-2.77 (EU). 
An investor affected by graphic health warnings on alcohol labels might also argue that they violate the FET standard by contradicting the investor's legitimate expectations. The Saluka tribunal determined that the FET obligation balances the right of the host State to exercise its regulatory authority in the public interest with the 'legitimate expectations' of foreign investors. ${ }^{71}$

In Philip Morris v Uruguay, the tribunal unanimously held that legitimate expectations depend on 'specific undertakings and representations made by the host State to induce investors' in making an investment. ${ }^{72}$ The tribunal went on to state that 'general legislation applicable to a plurality of persons ... do not create legitimate expectations that there will be no change in the law, ${ }^{73}$; a view consistent with decisions by various other tribunals. ${ }^{74}$ According to that line of reasoning, Thailand would not breach the FET obligation by failing to give effect to investors' legitimate expectations in the absence of specific representations to that investor or specific language in an IIA allowing such a basis for an FET claim.

It seems highly unlikely that the warning rule would fall foul of the FET standard. There seems to have been no specific representations from Thailand that alcohol would not be subject to label

Saluka Investments BV v Czech Republic, PCA, Partial Award (17 March 2006) paras 301-05. See also: Blusun S.A., Jean-Pierre Lecorcier and Michael Stein v. Italian Republic, ICSID Case No ARB/14/3, Award (27 December 2016) paras 365-371; Electrabel S.A. v. Republic of Hungary, ICSID Case No ARB/07/19, Award (25 November 2015) para 165.

72 Phillip Morris v Uruguay (n 29) paras 422-427: 'It clearly emerges from the analysis of the FET standard by investment tribunals that legitimate expectations depend on specific undertakings and representations made by the host State to induce investors to make an investment. Provisions of general legislation applicable to a plurality of persons or of category of persons, do not create legitimate expectations that there will be no change in the law.' (para 426). 'Given the State's regulatory powers, in order to rely on legitimate expectations the investor should inquire in advance regarding the prospects of a change in the regulatory framework in light of the then prevailing or reasonably to be expected changes in the economic and social conditions of the host State.' (para 427). See also: Campbell McLachlan, Laurence Shore and Matthew Weiniger, International Investment Arbitration: Substantive Principles (2nd edn, OPIL 2017) 316.

$73 \quad$ Phillip Morris v Uruguay (n 29) para 426.

74 EDF $v$ Romania, ICSID Case No ARB/05/13, Award (8 October 2009) para 217; CMS Gas Transmission Company v Argentine Republic, ICSID Case No ARB/01/8, Decision on Jurisdiction (17 July 2003) para 27; Parkerings v Lithuania, ICSID Case No ARB/05/8, Award (11 September 2007) para 331; Sempra Energy International v Argentine Republic, ICSID Case No ARB/02/16, Award (28 September 2007) paras 298, 299; OKO Pankki Oyj and Others $v$ Republic of Estonia, ICSID Case No ARB/04/6, Award (19 November 2007) paras 247-8, 263; Continental Casualty Company v Argentine Republic, ICSID Case No ARB/03/9, Award (5 September 2008) paras 258-262; Total SA v Argentine Republic, ICSID Case No ARB/04/1, Decision on Liability (27 December 2010) paras 119-20, 309; Charanne B.V. and Construction Investments S.A.R.L. v. Kingdom of Spain SCC Arb No 062/2012, Award (21 January 2016). See Rudolph Dolzer and Christoph Schreuer, Principles of International Investment Law (2nd ed, OUP 2012) 145-146. 
information. Although the use of graphic labels would be a world-first, it is not uncommon for countries to require health information on the product label and investors could not reasonably hold an expectation that Thailand would not introduce warnings, especially given the on-going nature of the discussions between Thailand and other members about this issue in the TBT Committee.

In regard to the marketing rule, however, there could be room for a legitimate expectations argument to be mounted. Whether such a claim arises will likely turn on how the measure is administered. In Lemire $v$ Ukraine, the tribunal held that an investor (in this instance, the broadcasting industry) could expect a regulatory system that was 'consistent, transparent, fair, reasonable, and enforced without arbitrary or discriminatory decisions'. ${ }^{75}$ As WTO Members contended (see above Part III.A.1), the boundaries of the prohibition on alcohol label marketing are unclear and allow a high degree of subjectivity in their enforcement. The measure prohibits a range of common alcohol marketing techniques, especially the use of certain terms that enable producers to describe and distinguish their products. This may lead investors to assert that their expectation-that they could employ basic marketing techniques including describing the objective qualities of their products - has not been met. Because alcohol producers need not obtain approval prior to engaging in marketing, in the absence of comprehensive regulatory guidelines and in the face of unclear decision-making by the regulator, a producer could find its marketing falling afoul of the measure, despite believing that it had complied. While some tribunals have dismissed an investor's subjective expectations as having little weight in a legitimate expectations assessment, tribunals have generally held that it is a factor to be considered. ${ }^{76}$ Because the marketing rule enables producers to ask the regulator if its proposed marketing strategy is compliant, a legitimate expectations claim might be more likely to succeed if the investor exercised due diligence by seeking such a clarification and received a positive response, upon which it relied. ${ }^{77}$

Joseph C. Lemire v. Ukraine, ICSID Case No ARB/06/18, Decision on Jurisdiction and Liability (21 January 2010), para 267.

See eg Saluka v Czech Republic (n 71) para 304; Invesmart, BV v Czech Republic, UNCITRAL, Award (26 June 2009), paras 250-55; Charanne v. Kingdom of Spain (n 74) para 495.

See eg Parkerings-Compagniet AS v Lithuania, ICSID Case No ARB/05/8, Award (11 September 2007), para 333; Invesmart, B.V. v Czech Republic (n 76) para 254. 
Issues concerning the marketing rule and its effect on registered trademarks might also arise in a similar fashion. For example, there is uncertainty over what constitutes a prohibited 'cartoon' under the marketing rule. While the measure protects trademarks registered before the measure's entry into force (and thus, any cartoons that might be present on the alcoholic beverage) ${ }^{78}$ it is silent on the treatment of trademarks registered after entry into force. To date, few disputes have arisen concerning measures affecting marketing and the use of trademarks. ${ }^{79}$ However, both the Philip Morris v Uruguay and more recent Bridgestone $v$ Panama tribunals have found that a trademark can qualify as an investment. ${ }^{80}$ For the latter tribunal, it held that 'a registered trademark will constitute a qualifying investment provided that it is exploited by its owner by activities that, together with the trademark itself, have the normal characteristics of an investment., ${ }^{, 1}$ Accordingly, an investor, whose registered trademark is found to be in breach of the measure, might argue that it had a legitimate expectation that once registered, its trademark was both compliant with the marketing rules and could be exploited.

\section{B Expropriation}

Protecting foreign investors from uncompensated expropriation by a host State is a cornerstone of the international investment regime. Such provisions, covering both direct and indirect expropriation, feature in nearly all IIAs. Whereas direct expropriation is typically a straightforward taking by the State (eg nationalising a factory), indirect expropriation may occur when a host State's regulation or other action has the effect of depriving a foreign investor of their property entirely, or significantly diminishes the amount and nature of the benefits the investor had originally contemplated. ${ }^{82}$ Often, it is difficult to delineate when a government measure crosses

Enquiry Point (n 37) 2, part (2)(d).

Known disputes include: Bridgestone Licensing Services, Inc. and Bridgestone Americas, Inc. v Republic of Panama, ICSID Case No ARB/16/34 (pending); Phillip Morris v Uruguay (n 29); Shell Brands International AG and Shell Nicaragua S.A. v. Republic of Nicaragua, ICSID Case No ARB/06/14, which settled prior to the tribunal rendering an award on the merits; and Philip Morris Asia Limited v. The Commonwealth of Australia, PCA Case No 2012-12, UNCITRAL, Award on Jurisdiction and Admissibility (17 December 2015) which was bifurcated and dismissed by the tribunal at the jurisdiction and admissibility stage.

Phillip Morris v Uruguay (n 29) para 274; Bridgestone Licensing Services, Inc. and Bridgestone Americas, Inc. v Republic of Panama, ICSID Case No ARB/16/34, Decision on Expedited Objections (13 December 2017), para 177. Bridgestone $v$ Republic of Panama (n 80), para 177.

Andrew Newcombe and Lluís Paradell, Law and Practice of Investment Treaties: Standards of Treatment (Kluwer Law International 2009) 18, 24; Jeswald Salacuse, The Law of Investment Treaties (2nd edn, OUP 2015) 316.

Page 18 of 25 
the line from valid regulation to compensable expropriation. ${ }^{83}$ Relevant factors include the loss of control by the investor ${ }^{84}$ and the destruction of value of the investment. State actions constituting a bona fide exercise of sovereign police powers will not normally constitute an expropriation, affording host States a degree of policy space to regulate in the public interest. ${ }^{85}$

Looking first at expropriation under international investment law: Thailand's warning or marketing rules for alcoholic beverages, if implemented, could amount to expropriation under a traditional IIA only if it effected a 'substantial deprivation' of the value, ${ }^{86}$ use or enjoyment of an investment, which might take the form of brands, trademarks and goodwill. ${ }^{87}$ The Philip Morris $v$ Uruguay tribunal unanimously determined that 'as long as sufficient value remains after the Challenged Measures are implemented, there is no expropriation' and that 'a partial loss of the profits that the investment would have yielded absent the measure does not confer an expropriatory character on the measure'. ${ }^{88}$ In that case, the tribunal unanimously found that Uruguay's so-called $80 / 80$ regulation, limiting the promotional material to $20 \%$ of the package, could not have a 'substantial effect' on Philip Morris' investment. ${ }^{89}$ When viewed in isolation, Thailand's health

Salacuse (n 82) 326; Marvin Roy Feldman Karpa v United Mexican States, ICSID Case No ARB(AF)/99/1, Award (16 December 2002), para 100; Saluka v Czech Republic (n 71) paras 263-64.

Nykomb Synergetics Technology Holding AB v The Republic of Latvia, SCC Case No 118/2001, Award (16 December 2003), s 4.3.1.

There are two main doctrines when determining whether a governmental measure constitutes an indirect expropriation, namely the sole effects doctrine and the police powers doctrine. The sole effects doctrine provides that only the effect of the alleged expropriation measure shall be taken into consideration. The police powers doctrine, however, sets up a test of all relevant circumstances when making the determination, such as the purpose, the context and nature of the measure. The police powers doctrine provides that if a measure is taken in the exercise of the State's police powers, the State will not be liable for any claim of expropriation as a result of that measure, as it recognises the right of a State to regulate commercial and business activities within its territory. The police powers refer to the State's powers to enact bona fide, non-discriminatory measures for the protection of public welfare. See eg Suez $v$ Argentina, ICSID Case No ARB/03/17, Decision on Liability (30 July 2010) paras 128, 147-148; Fireman's Fund Insurance Company $v$ The United Mexican States, ICSID Arbitral Award, Case No ARB(AF)/02/01, Award (17 July 2006) para 176(j); Saluka v Czech Republic (n 71) paras 254-255, 257-258, 261-262, 275-276; Técnicas Medioambientales Tecmed SA $v$ Mexico, ICSID Case No ARB(AF)/00/2, Award (29 May 2003) para 119.

Telenor Mobile Communications AS v. Republic of Hungary (Award, 13 Sep. 2006), paras 65, 70; Metalclad Corporation v Mexico, ICSID Case No ARB(AF)/97/1, Award (30 August 2000), para 103; CME Czech Republic BV $v$ Czech Republic, UNCITRAL, Partial Award (13 September 2001) para 688; Pope \& Talbot Inc v Canada, NAFTA Ch 11 Arbitral Tribunal, Award on the Merits of Phase 2 (10 April 2001) paras 96, 102.

Phillip Morris v Uruguay (n 29) paras 192, 284.

Ibid para 286. See also Ursula Kriebaum, 'Partial Expropriation' (2007) 8 Journal of World Investment \& Trade 69. Phillip Morris v Uruguay (n 29) para 276. See also Tania Voon, 'Philip Morris v Uruguay: Implications for Public Health' (2017) 18 JWIT 320, 335. 
warnings covering 30-50\% would be similarly unlikely to constitute a substantial deprivation and thereby expropriation.

However, an investor might also argue that the cumulative effect of the size of the warning combined with other aspects of the measure (e.g. standardisation of text and colours, the chosen content of warnings), and the marketing rule (with its prohibition on the use of certain images and terms) further diminishes value, tantamount to an expropriation. Tribunals have routinely recognised that, at international law, a State may engage in 'creeping expropriation' over a period of time 'even though the State does not purport to have expropriated property and the legal title to that property formally remains with the original owner'. ${ }^{90}$ Some IIAs also explicitly recognise the notion of creeping expropriation. ${ }^{91}$ Recently, the tribunal in Teinver $v$ Argentina held that, to prove the existence of a creeping expropriation, the relevant enquiry is 'the effect or result of the measure, as opposed to the purpose for which each measure was undertaken,${ }^{92}$ Following this reasoning, Thailand would not be able to argue that each measure should be assessed independently, or that they served different ends.

That said, even if an investor can demonstrate a regulatory taking of its investment, the measure may be non-expropriatory if it falls within the host State's recognised police powers. ${ }^{93}$ Investment tribunals seldom articulate the parameters of police powers, particularly with regard to the type of regulatory action that would be excessive or 'disproportionate' to the policy objective. ${ }^{94}$ The Tecmed $v$ Mexico tribunal stated that there 'must be a reasonable relationship of proportionality between the charge or weight imposed to the foreign investor and the aim sought to be realized by

AIG Capital Partners, Inc. and CJSC Tema Real Estate Company v Republic of Kazakhstan, ICSID Case No ARB/01/6, Award (7 October 2003), section 10.3.1 (citing Starrett Housing v Iran, Interlocutory Award of 19 December 1983, 4 Iran-US CTR 122). See also: Generation Ukraine v Ukraine, ICSID Case No ARB/00/9, Award (16 September 2003), para 20.22; Compañía de Aguas del Aconquija S.A. and Vivendi Universal S.A. v Argentine Republic, ICSID Case No ARB/97/3, Award (20 August 2007), para 7.5.31; Biwater Gauff (Tanzania) Limited v United Republic of Tanzania, ICSID Case No ARB/05/22, Award (24 July 2008), para 455; Spyridon Roussalis v Romania, ICSID Case No ARB/06/1, Award (1 December 2011), para 329;

91 See, eg, United States Model Bilateral Investment Treaty (2012) annex B ('Expropriation') [4]: 'action or series of actions'.

92 Teinver S.A., Transportes de Cercanías S.A. and Autobuses Urbanos del Sur S.A. v. Argentine Republic, ICSID Case No ARB/09/01, Award (21 July 2017), paras 948-51.

$93 \quad$ Fireman's Fund $v$ The United Mexican States (n 85) para 176.

94 Caroline Henckels, 'Indirect Expropriation and the Right to Regulate: Revisiting Proportionality Analysis and the Standard of Review in Investor-State Arbitration' (2012) 15 JIEL 223, 234; José E. Alvarez, 'The Use (and Misuse) of European Human Rights Law in Investor-State Dispute Settlement' in Franco Ferrari (ed), The Impact of EU Law on International Commercial Arbitration (Juris 2017) 75. 
any expropriatory measure'. ${ }^{95}$ That decision has been criticised as 'second-guessing the importance of the authorities' motivations and conducting proportionality analysis in a methodologically problematic way'. ${ }^{96}$ More recently, in Philip Morris $v$ Uruguay, the tribunal unanimously determined that Uruguay's challenged tobacco labelling requirements were a valid exercise of its police powers for the protection of public health. ${ }^{97}$ After a broad survey of relevant jurisprudence, the tribunal held that, to constitute a valid exercise of police powers in the context of health, the State's measure must be:

- non-discriminatory;

- bona fide for the purpose of protecting the public welfare; and

- proportionate to the objective the measure was meant to achieve. ${ }^{98}$

In summary, the most significant criteria for assessing whether the warning and marketing rules constitute a valid exercise of police powers under international investment law are whether the labelling requirements are reasonably related to a rational policy, and whether their impact on an investor is proportionate to their objective. ${ }^{99}$ There is some overlap in the nature of the inquiries made with respect to police powers and those relating to the 'arbitrariness' analysis for FET.

In making an assessment about the application of the police powers doctrine, a tribunal may consider evidence as to: (1) whether graphic health warnings and removal of certain images and terms on alcoholic beverage labels reduce the consumption of alcohol, as well as (2) the causal relationship between alcohol consumption and alcohol-related harm. The Philip Morris v Uruguay tribunal considered the scientific basis of these two different causal relationships in the context of tobacco, concluding that Uruguay's 80/80 requirement was reasonable. The tribunal found that this particular labelling requirement 'had some deterrent effect on smokers ... especially in new

Técnicas v Mexico (n 85) para 122.

See, eg, Caroline Henckels, Proportionality and Deference in Investor-State Arbitration (Cambridge University Press, 2015) 110. Henckels' specific criticisms of the tribunal's award are its 'subjectivity, failure to assess relevant considerations, and lack of appreciation for the context of the decisions taken. Furthermore, the tribunal's reliance on ECtHR cases was selective and, as a result, misleading': 110.

Phillip Morris v Uruguay (n 29) para 307.

Ibid paras 305-306.

Phillip Morris v Uruguay (n 29) paras 305-306, 409. 
smokers and young smokers' (the label/consumption relationship), ${ }^{100}$ and that there existed 'strong scientific consensus as to the lethal effects of tobacco' (the consumption/harm relationship). ${ }^{101}$ In practice, while the calculation of proportionality and reasonableness can be highly subjective and variable, ${ }^{102}$ various tribunals have identified a 'margin of appreciation'103 or accorded significant 'deference' 104 to States in designing their public policy measures. For example, the Philip Morris $v$ Uruguay tribunal noted that substantial deference was accorded to matters of public policy regarding 'acknowledged and major public health problems' and that only measures that were 'entirely lacking in justification' or 'wholly disproportionate' would breach FET. ${ }^{105}$ These notions of 'margin of appreciation' and 'deference' for governmental approaches of public health policies could also potentially benefit Thailand and other countries in the context of the application of the police powers doctrine, particularly in circumstances where it may not be possible to isolate the impact of a particular measure (eg the individual effect of one of its six graphic labels) and where the reduction in consumption and harm are more distal impacts of labelling measures than changes in knowledge and attitudes.

Another point of note is that the key reason that the Philip Morris tribunal found Uruguay's 80/80 regulation both reasonable and proportionate was the international legal basis for tobacco control. The tribunal unanimously relied on Uruguay's international legal obligation to protect public health under the WHO Framework Convention on Tobacco Control (FCTC) ${ }^{106}$ and related guidelines ${ }^{107}$ in determining that the $80 / 80$ regulation breached neither the FET ${ }^{108}$ nor the

Ibid para 417.

Ibid para 418.

Federico Ortino, 'Investment Treaties, Sustainable Development and Reasonableness Review: A Case Against Strict Proportionality Balancing' (2017) 30 Leiden J Intl L 71, 74; Jürgen Kurtz, The WTO and International Investment Law: Converging Systems (CUP 2016) 202; Caroline Henckels, 'Indirect Expropriation and the Right to Regulate: Revisiting Proportionality Analysis and the Standard of Review in Investor-State Arbitration' (2012) 15 JIEL 223, 250.

Chemtura Corporation v Canada, UNCITRAL, NAFTA Ch 11 Arbitral Tribunal, Award (2 August 2010) paras 123 and 242.

TECO v Guatemala, ICSID Case No ARB/10/17, Award (19 December 2013) paras 490-493.

Phillip Morris v Uruguay (n 29) paras 418-419.

WHO Framework Convention on Tobacco Control, 2302 UNTS 166 (adopted 21 May 2003, entered into force 27 February 2005).

WHO Guidelines for Implementation of Article 11 of the WHO Framework Convention on Tobacco Control.

Phillip Morris v Uruguay (n 29) paras 401, 420. 
expropriation obligation. ${ }^{109}$ The tribunal relied on FCTC's specific obligation that a warning consist of $30-50 \%$ of the product's display area. ${ }^{110}$ Although not a binding treaty akin to the FCTC, the WHO's Global Alcohol Strategy might be raised to support health warnings on alcohol labels such as Thailand's proposal. However, the Global Alcohol Strategy is not prescriptive about the format of the warnings compared to the FCTC. ${ }^{111}$ It also includes a weak recommendation with respect to alcohol marketing, ${ }^{112}$ which offers limited, if any, support to Thailand in the event of a dispute.

\section{CONCLUSION}

Between its warning and marketing measures, Thailand has tightened the screws on the alcohol industry's use of the packaging for promotional purposes. Thailand's proposal for graphic warning labels on alcoholic beverages represented a major step forward for alcohol control. Although the proposal has not yet come to fruition, it seems likely that Thailand or some other country will eventually take alcohol labelling in the same direction as tobacco labelling. The restrictions on label marketing also goes much further than any other country's regulation of alcohol label marketing. The reaction to these measures by those WTO members who are home to major producers of alcohol, especially wine and spirits, suggests that trade or investment law challenges to the marketing rule or the warning rule (should it come into effect) are possible. The marketing rule, in particular, is causing on-going agitation for WTO members, but they also remain alert to the possibility of the proposal for warning rule being resurrected.

This article has reviewed the implications of international investment law, in particular the rules as to FET and expropriation, for Thailand's labelling rules. Uncertainty remains as to the level of scientific evidence required to defend investment challenges based on these obligations, and the

The Tribunal emphasised that Uruguay adopted the challenged measures in fulfilment of its 'national and international legal obligations for the protection of public health,' when considering the scope of the police powers doctrine: ibid paras 302, 304.

110 Ibid para 412.

111 For example, the WHO's Global Alcohol Strategy suggests the policy option of 'providing consumer information about, and labelling alcoholic beverages to indicate, the harm related to alcohol': WHO, 'Global Strategy to Reduce the Harmful Use of Alcohol' (2010) 17. Further, in determining that the 80/80 Regulation did not breach the FET standard, the tribunal considered with reference to the WHO FCTC that the principle of large health warnings is internationally accepted; it is for governments to decide on their size, and they are encouraged to require health warnings of 50\% or more': Phillip Morris v Uruguay (n 29) para 412.

WHO, 'Global Strategy to Reduce the Harmful Use of Alcohol' (n 111) 15-16. 
associated level of deference accorded to States. ${ }^{113}$ This ambiguity as to the requisite level of scientific evidentiary basis has given rise to a recent recalibration of the language contained in recent IIAs. ${ }^{114}$ But notwithstanding this uncertainty, our view remains that Thailand or countries introducing similar measures would likely be able to withstand a challenge to the graphic warning labels. Thailand is assisted by the mounting evidence about the potential for alcohol warning labels, especially those which include large pictograms, to influence a range of variables relevant to reducing consumption. It would be very useful for further research on labelling to consider the impact of photograph-style graphics on consumer perceptions, attitudes and behaviour relating to alcohol.

We are more tentative that Thailand's marketing rule would be found consistent with international investment law. The banning of all 'cartoons' is an area of weakness in the rule. The other problematic aspect of the rule is the restriction on descriptions which exaggerate 'the benefit or quality of alcoholic beverages'. With both of these rules, the discussions in the WTO TBT Committee are directed to getting clarity about the scope of these restrictions. If Thailand were to attribute a broad meaning to these terms, it is possible that they would be found in breach of the rules on FET and expropriation. There is no evidence which would support the removal of all 'cartoons' which are in the form of hand-drawn images from alcoholic beverages, for example. Nor is there evidence that taking away descriptions of the objective properties of an alcoholic beverage would assist in reducing consumption and harm. Thailand, or other countries considering like rules, would be well advised to sharpen the drafting of these rules to more closely align with the evidence base. This would assist with an argument that the measure is reasonable and proportionate to the aim of reducing exposure to marketing which encourages beliefs and attitudes which drive alcohol consumption and associated harm. Thailand's measure also points to new future areas of research in respect of alcohol marketing. Very little is known about how alcohol label marketing and its restriction affect consumer behaviour. It is an area that would benefit

Voon (n 89) 330; Henckels (n 96) 186-187.

See generally, Suzanne Spears, 'The Quest for Policy Space in a New Generation of International Investment Agreements' (2010) 13 JIEL 1037; Caroline Henckels, 'Protecting Regulatory Autonomy through Greater Precision in Investment Treaties: The TPP, CETA and TTIP' (2016) 19 JIEL 27; Christian Tietje and Kevin Crow, 'The Reform of Investment Protection Rules in CETA, TTIP and Other Recent EU-FTAs: Convincing?' in Stefan Griller, Walter Obwexer and Erich Vranes (eds), Mega-Regional Trade Agreements: CETA, TTIP, and TiSA: New Orientations for EU External Economic Relations (OUP 2017); Mark Manger and Clint Peinhardt 'Learning and the Precision of International Investment Agreements' (2017) 43 Intl Interactions 920. 
undoubtedly from further investigation, especially in light of learnings about the effects of the tobacco packaging on consumers. 


\section{University Library}

\section{- M M I N E R VA A gateway to Melbourne's research publications}

Minerva Access is the Institutional Repository of The University of Melbourne

Author/s:

Mitchell, A;O'Brien, $\mathrm{P}$

Title:

If One Thai Bottle Should Accidentally Fall: Health Information, Alcohol Labelling and International Investment Law

Date:

2020

Citation:

Mitchell, A. \& O'Brien, P. (2020). If One Thai Bottle Should Accidentally Fall: Health Information, Alcohol Labelling and International Investment Law. Journal of World Investment and Trade, 21 (5), pp.674-697. https://doi.org/10.1163/22119000-12340191.

Persistent Link:

http://hdl.handle.net/11343/251146 